\title{
PRODUCT AND SERVICE QUALITY IMPROVEMENT IN MANUFACTURING: A STUDY OF OPTICAL LENS MANUFACTURING IN INDONESIA
}

\author{
Refli Simbolon \\ Master of Management Student, Mercubuana University, Jakarta Indonesia \\ email: rere.dreamer@gmail.com \\ Sugeng Santoso \\ Lecturer of Magister Management Program, Mercubuana University, Jakarta Indonesia \\ email: sugeng.santoso@mercubuana.ac.id
}

Received: October 2020; Accepted: January 2021; Available online: January 2021

\begin{abstract}
For optical lens manufacturing continuous improvement of product and service quality is key in answering challenges in business competition in their field. To achieve this, optical manufacturing forms a Kaizen work culture that is committed to sustainable development. The Key Performance Indicator (KPI) specified of the product Rejected Rate is $3.5 \%$ and to On Time Delivery (OTD) of the service is 4 days. Continuous Improvement Kaizen culture with development methods through value chain analysis applied to achieve KPI targets in this research succeeded in lowering the Rejected Rate KPI rate by $0.46 \%$ and increasing OTD by $2.22 \%$. The method used in this study uses a qualitative approach with a review of literacy studies, observations and direct interviews to plant managers of one of the largest optical lens manufacturers in Indonesia using data comparisons in 2018 and 2020 as well as to 100 Store managers \& Optical Stores Customers.
\end{abstract}

Keywords: product and service quality; continuous improvement of Kaizen; optical lens manufacturing.

\begin{abstract}
Bagi manufaktur lensa optik perbaikan terus-menerus terhadap kualitas produk dan layanan adalah hal kunci dalam menjawab tantangan dalam persaingan bisnis di bidangnya. Untuk mencapai hal tersebut manufaktur optik membentuk budaya kerja Kaizen yang berkomitmen pengembangan berkelanjutan. Key Performance Indikator (KPI) yang ditetapkan dari Rejected Rate produk adalah 3,5\% dan pada On Time Delivery (OTD) dari layanan adalah 4 hari. Pengembangan berkelanjutan sesuai budaya Kaizen dengan metode pengembangan melalui analisis rantai nilai yang diterapkan guna pencapaian target KPI dalam penelitian ini berhasil menurunkan angka KPI Rejected Rate sebesar 0.46\% dan menaikkan OTD sebesar $2.22 \%$. Metode yang digunakan dalam penelitian ini menggunakan pendekatan kualitatif dengan tinjauan studi literasi, observasi dan wawancara langsung terhadap plant manager salah satu manufaktur lensa optik terbesar di Indonesia dengan menggunakan perbandingan data tahun 2018 dan tahun 2020 serta kepada 100 Store manajer \& pelanggan toko optik.
\end{abstract}

Kata kunci: kualitas produk dan layanan; perbaikan terus-menerus dari Kaizen; manufaktur lensa optik.

How to Cite: Product and Service Quality Improvement in Manufacturing: a Study of Optical Lens Manufacturing in Indonesia. Media Ekonomi dan Manajemen, 36(1), 76-88. doi: http://dx.doi.org/ 10.24856/mem.v36i1.1726. 


\section{INTRODUCTION}

To have an advantage in competing in the optical lens industry, optical lens manufacturing is required to produce quality lenses in accordance with customer expectations of what optical staff has offered on the front line. But it doesn't just stop there, the length of the work process becomes added value from the services offered. Of course, all customers want a faster range of processing time because glasses are a very vital aid that as soon as possible wants to be used.

To produce a lens with good optical quality requires a good production quality standard. Each lens manufacturer has a quality standard which is a shift to measuring a product to be sent to the customer or not. To keep product quality maintained at its standards, the role of Quality Control (QC) becomes very important as a decision-maker whether a product meets quality standards. QC also plays an important role in continuous improvement by communicating with each issue to all relevant departments. Any product that does not match the standard must be rejected and restarted from the beginning this will certainly be related to operational costs. The failure of the product will cause the time span of the work process to be longer, surely this will cause complaints to the customer and the optical image ends that sell the lens product from the manufacturing to be poorly arranged by the customer and if so too often, not a few optical companies move to other optical lens manufacturers. For these reasons, manufacturing must always develop the system and its ability to be able to compete. The improvement of a manufacturing system is in one business carried out by the company, in order to be able to respond to changes that must be controlled at all times to see market conditions in the world (Hendri et al, 2020).

The following is the flow of the production process of a lens ordered by optics to optical lens manufacturing (Figure 1):

Independent optics and optical chain stores which are a group of the manufacture order lenses to the Lab (manufacturing), through web programs that are already installed on each optic that works together. When received by a lab server. then printed into an order note with the order number according to the order quantity on which day it entered, also with the optical identity of the order. Then the production process begins as follows:

\section{First: Warehouse}

The warehouse department (lens warehouse) issues the lens according to the order received. The lens consists of two types of semi-finished lenses and finishes lenses. A semi-finished lens is a lens that requires further processing according to the order data received. Finished lens is a lens that is already available and ready to be faceted (cut) according to the frame that is ordered. For semi-finished lenses, the next process is passed on to the surfacing department while the finished lens is direct to the edging department (Cutting).

Second: Surfacing

The Surfacing Department carries out several processes in it:

Calculating: The process of calculating power (lens size), The focal point of the lens is adjusted to the available lens diameter.

Blocking: Attach the block to the lens as a handle when the lens is rubbed.

Taping: $\quad$ The process of coating the lens with a plastic sticker on the part that is not rubbed to avoid damage during the rubbing process.

Generating: Rubbing the back of the lens to get the curvature design needed to form the power and design of the lens. 
Engraving: The process of marking the lens according to the brand and type of lens using a laser beam.

Polish: The process of cleaning the lens from the remnants of the material that is still attached.

Deblocking: The process of removing blocks mounted on the lens.

Third: Quality Control 1

QC1 is tasked with examining the work of the surf department, whether it is appropriate to continue the subsequent provisions of the Coating. If the production results do not meet the eating standard the process is stopped and repeated from the beginning again.

\section{Fourth: Coating}

Department Coating (layer) performs several stages of the process:

Precleaning: Cleaning the lens before it is cooked into a coating machine.

Hardcoat: Coats the lens with a hardcoat coating that functions so that the lens becomes more slippery and becomes more scratch resistant.

Multicoat: Coat lenses with various layers (Coating) that comply with lens specifications and special orders.

Fifth: Quality Control 2

QC2 is tasked with examining the work of the coating department, whether it is appropriate to continue the subsequent provisions of the edging. If the production results do not meet the eating standard the process is stopped and repeated from the beginning again.

\section{Sixth: Edging}

The edging department cuts the lens according to the frame order data received.

Seventh: Quality Control 3
QC3 is tasked with examining the work of the Edging department, whether it is appropriate to pass further provisions namely packaging and shipping to optical ordering. If the production results do not meet the standard, then the process is stopped and repeated from the beginning again.

\section{LITERATURE REVIEW Product and Service Quality}

Product quality is the characteristic of a product or service that bear on its ability to satisfy stated or implied customer needs (Kotler \& Amstrong, 2012). Ehsani and Ehsani (2015), said that quality of product is the customer's perception of the overall quality or superiority of the product or service, with respect to its intended purpose, relative to alternatives. Garvin's eight dimensions of Product Quality in Performance, Features, Reliability, Conformance, Durability, Serviceability, Aesthetics and Perceived quality are dimensions of Product Quality that affect Customer Satisfaction which impacts Loyalty (Hoe \& Mansori, 2018).

Definition of service quality according to Tjiptono (2007), as an effort to meet the needs and desires of consumers and the accuracy of shipping in balancing consumer expectations. service quality dimensions are significant predictors of customer satisfaction and loyalty with the commitment dimension accounting for the highest degree of this impact (Izogo \& Ogba, 2015).

Based on the above definition if associated with this study, product quality is the quality of the production of optical lenses produced must be following the standard that has been determined from the power side and cosmetics, while service quality is the acceleration of the period of the eyeglass lens production process to meet customer expectations and desires. 


\section{Kaizen Work Culture for Continuous Improvement with Value Chain Analysis Method}

An organization that developed and developing an organization that managed to build an ethos or culture of working employees at all levels. Robbin (2002) explains that the practical work culture contains several definitions patterns of values, attitudes, behaviors, intentions, and results of the work, including instruments, systems, technology, and the language it uses. Meanwhile, according to Nawawi (2003), understanding the working culture is a habit that is run repeatedly by the employees in an organization. There is a very famous work culture of the State Sakura Japanese Kaizen has also used as a model the work culture in manufacturing optical lenses as the research object that is Kaizen. Kaizen by Imai (2008), is "continuous progress and improvement in one's life, family life, social life, and working life". Kaizen is "a simple concept, which is composed of two characters namely: Kai meaning change and Zen meaning well, so if combined into one word then literally have to mean "improvement ". Kaizen is a continuous improvement that involves all members of the company by creating new ways of thinking and process-oriented management systems that support and reward employee efforts.

Kaizen is a Japanese word, which implies any change for good. It implies that continuously done small changes help in improving manufacturing techniques and processes (Kumar, 2019). Kaizen focuses on simplification by breaking down complex processes into subprocesses and then fix it. Typically, Kaizen started by producing efficiently with limited resources; human, material, machinery (Abdulmouti, 2018).

Continuous improvement is an organized attempt to find out and apply new ways of doing work for making process improvements by bringing step by step innovations to work and this could be possible by Involving top to bottom employees to bring new ideas to work place (Khan et. al., 2018). According to Joergensen, Boer and Laugen, (2006), Continuous Improvement is the process of planned, organized, and systematic changes that are ongoing, gradual and across the enterprise in practice running, and aims to improve the performance of the company. To continue to monitor the results of improvement needs to be monitored (monitoring) and auditing. Results of monitoring and auditing can be used as a reference for the development or improvement of sustainable (Santoso \& Mayrifka, 2019).

According to Pearce and Robinson (2013), the value chain is a method of viewing the company as a decaying activity that turns inputs into valuable output for customers. Whereas according to Porter (1985), Value chain is a series of activities carried out by companies made specifically to produce goods or services. Porter further explained the understanding of the value chain model, which is a tool to identify various ways of generating value or value for consumers, where this model displays the overall value consisting of various value and profit activities (margin). This value activity is divided into five main activities (Primary Activities) and four supporting activities (Support Activities).

Primary Activities consists of:

Inbound Logistics

Operations Management

Outbond Logistics

Marketing and sales

Service

\section{Support Activities consist of:}

Company infrastructure

Human resource management

Technology

Procurement

\section{Competitive Advantage}


Market orientation is an organizational culture that is most effective and efficient at creating the necessary behaviors for the creation of superior value for customers so that they can generate superior business performance on an ongoing basis (Haryanto, 2019). The competitive advantage gained when organizations develop or acquire a set of attributes (or action execution) that enable it to outperform its peers (Wang, 2014). In another sense, the competitive advantage is visible when the activities of certain organizations more profitable than competitors' market or when outperform those concerning to the results other important activities (Huff et al., 2009). The problem becomes even more important competitive advantage as a result of growing turbulence in the business environment. As seen, today is the ability of companies to adapt to the environment will increase. Therefore, the source of advantages such as flexibility or dynamic capability will have a major role as well as the values of the organization and learning organizations, which have the character of intangible (Cegliński 2016). The framework research can be described in Figure 2.

\section{RESEARCH METHODS}

This study uses a study of literacy and qualitative approaches. Sugiyono (2010), explains that the method of qualitative research is a research method that is based on the philosophy of postpositivism, is used to examine the condition of the object that is natural, where researchers are a key instrument, a sampling data source is purposive and snowball, techniques of collecting by triangulation (combined), data analysis is inductive or qualitative and qualitative research results further emphasize the significance of the generalization. According to Maleong, (in Herdiansyah 2010), Qualitative Methods is scientific research that aims to understand a phenomenon in social contact naturally with the advanced process of interaction between researcher in-depth communication with the phenomenon.

The Research was conducted on an optical lens manufacturing in Jakarta, which is a group of an optical retail company in Indonesia. which has more than 100 stores spread almost all over Indonesia. Data were collected through observation, documentation, and interviews with managers at the manufacturing plant, as well as to 100 store managers \& optical stores customers. 


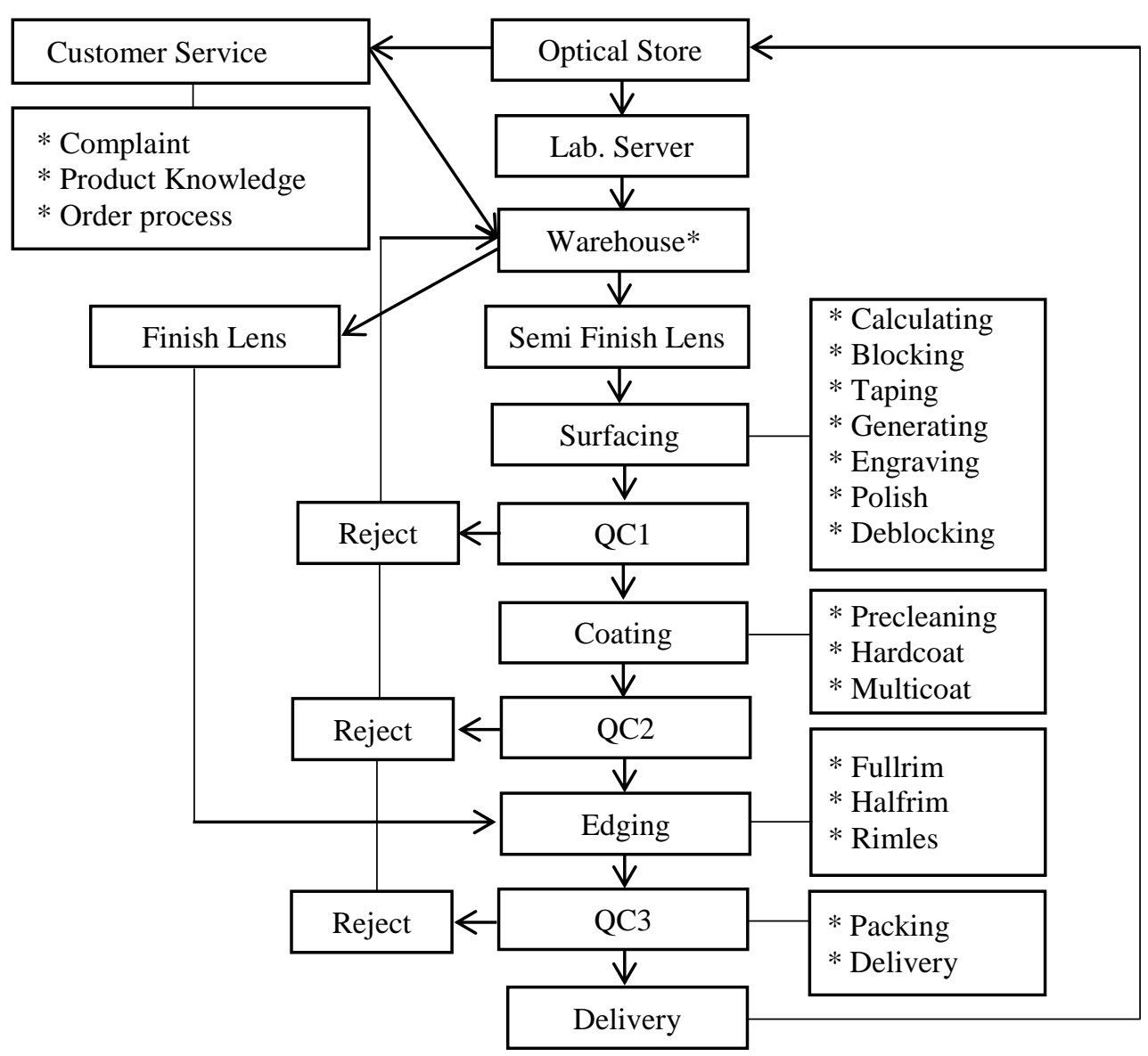

Figure 1. Flow of Lens Production Process

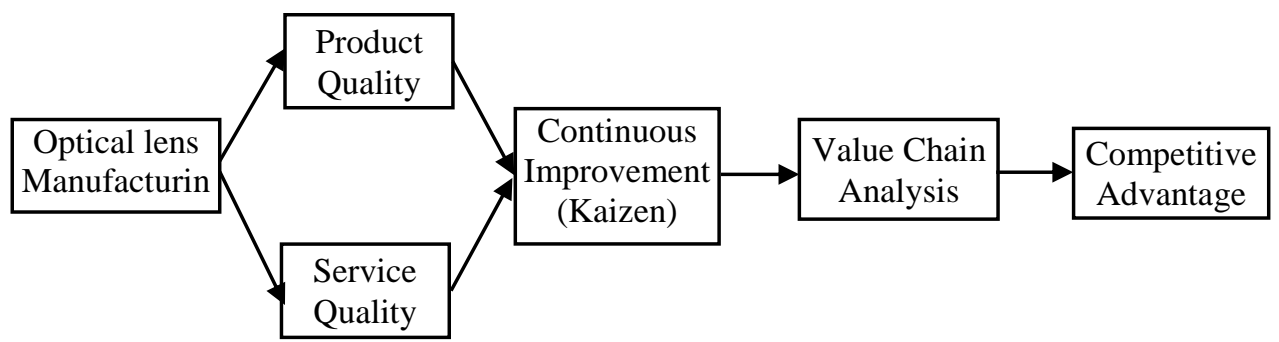

Figure 2. Framework Research

\section{RESULT AND DISCUSSION}

In 2018, manufacturing and move into the new building, but it is still the same in the city. In the new building began the process of transformation of the development of product quality and service. Results of research conducted by comparing the data in 2018, where the process begins with the development of KPI results in 2020. So, score a few in the following findings:

\section{Determination the Standard of KPI}

KPIs are defined as strategic and measurable measurements that reflect critical business success factors (ISO $22400,2014)$. is also a financial and nonfinancial indicator used by organizations to estimate and strengthen how successful they are, which aims to achieve long-term goals that have been previously set (Velimirović et al, 2011). Whereas Warren (2011), defining KPIs is a measurement that assesses how an organization executes its strategic vision. The intended strategic 
vision refers to how the organizational strategy is interactively integrated into the overall organizational strategy. To make the KPI Definition more appropriate in evaluating operational performs in industrial processes, it is necessary to know how the industrial processes that take place in converting raw materials into finished goods (Li Zhu et. al., 2017).

Optical Lens Manufacturing which was the object of this study had KPI namely Rejected Rate and On-Time Delivery (OTD. Rejected Rate is the KPI used to measure the failure rate of the production process compared to the total amount of production for one month (Percentage). Whereas On-Time Delivery is measuring delays orders in one month compared to total orders for one month. The two KPIs above have linkages, the production process that experiences many failures will cause many orders that will be delayed or in other words, the high Rejected Rate will affect the On-Time Delivery.

KPI is a means to be able to measure the extent of the operational run following the specified standards. In determining the operational standards must be following the organization's goals of providing better quality and faster processing. Then in 2018 in ordain KPI for the standard process of the lens. KPI setting process is to analyze each stage of the production process (value chain) with the following data:

From the Table 1, it can be seen that the pair of lenses takes 7.2 hours. Plus, the administrative process when the server receives data from the optical order of about 15 minutes. So overall the average total production was 7.5 hours. But the total time the process has not counted the long queue. The length of time the queue is very dependent on the orders of the day. So that the total processing time specified in the KPI On-Time Delivery is 4 working days and the KPI in the Rejected Rate is set at $3.5 \%$.
This designation is determined by considering the cost of production due to the number of the lens production process that failed and the risk of delays in the process of lens to customer orders and the factors appointment time to customer service is also being one of the key factors of competitiveness of service to competitors.

\section{Application of Porter's Value Chain Analysis to Continuous Improvement}

One way that is used to achieve sustainable development in manufacturing is to implement Kaizen work culture. Kaizen applied work culture makes the development process continues to run. Input improvement is based on the complaints and feedback from the front line of optical-optical collaboration with manufacturing. The Input was discussed at regular meetings weekly and monthly action plan which is then used to plan short-term and long-term.

The method used in making continuous improvement is by value chain analysis from Porter. The analysis used in this study is the use of a value chain model proposed by Porter as follows:

\section{Main Activities}

\section{Logistic Incoming}

The quality of the lens raw materials, it is greatly affecting the quality of products. On manufacture make arrangements with suppliers, which do not meet quality lens will cut payment. But less well-recognized lens quality is a lens that has not entered the production process. So that does is make Incoming Station for checking the quality of lenses (cosmetic qualities: scratches, spots, etc.) before entering the production process.

\section{Operations Management}

Surely operations management has a very vital role in the quality of production. 
For that management made several strategic measures including:

\section{Maintenance}

Perform calibration of the machinery of production and maintenance for all production machines to ensure the condition and quality of utilities, such as water quality, humidity, cleanliness, air pressure, room temperature, and the temperature of cold water (chiller) to be monitored.

\section{Additions Production Line}

As the number of good partners, the optical optics group of companies as well as independent optical line management did increase production to 2 lines. This is certainly a very significant increase in the production capacity of the company which led to an increase in the service order process period and improve KPI On-Time Delivery.

\section{Logistics Exit}

To ensure the products to customers in addition to developing an internal department that serves optical expedition partners in the cities and provinces of manufacturing also cooperate with reputable external expeditions and commitment are aligned.

\section{Marketing \& Sales}

For marketing and sales activities to the Independents optical, the management of the sales department in charge of marketing their products and maintain good relations with the optical-optical partner who has been working. The marketing activities are carried out directly by the optical-optical visit in all regions in Indonesia and negotiate directly with the owner. Branding activities also performed well in print and on-line. And to increase sales in the optical group company, joint management incentive scheme suppliers make a trip to the best sales team in sales lens with defined KPI.

\section{Services}

Service is very considered, for the improvement of customer services is done by adding the line phone operator and also build the information system checks the order through the website that can be accessed anytime and anywhere.

\section{Supporting Activities}

\section{Infrastructure Company}

For service, improvements can be made quickly and effectively split the management of the organization by increasing the customer service department.

\section{Human Resource Management (HRM)}

Development of HRM done by the following methods:

\section{Training}

Provide basic and advanced training for all employees to achieve the appropriate competence and expertise standards. For some materials that advance, the management also requested that the supplier provide training to transfer knowledge (Knowledge sharing) to the operator.

\section{Allowance}

Since work on optics manufacturing requires precision is very high, especially in the $\mathrm{QC}$, the company provides free glasses for employee benefits every year so that maximum operator vision at work.

\section{Recess Period}

Create a schedule enough rest in the morning and afternoon so employees can rest the vision to be able to return to work with high precision.

\section{Incentives and Penalties}

Management also implemented incentives and bonuses for 
employees who excel as well as fines and penalties for employees who often make mistakes in the work, it is certainly very effective regards motivate employees to work.

\section{Technology}

The use of technology in the operations of a business becomes a key success of companies in the face of today's business competition. For that management periodically renew the production equipment with the latest technology especially those having artificial intelligence and digital devices that can allow the operator to work and reduce production time. As a first example of the calculation process is fully carried by the operator so that the error rate is high enough and long enough processing time. Currently, $95 \%$ is done by a machine and the results are very good and fast. Information technology over the Internet is also used for checking the booking process and transmit a dataorder lens whenever and wherever.

From the data by utilizing the calculation scrubbing technology in Table 2 , the upgraded equipment surfacing machine managed to lose rejected rate from $3.80 \%$ to $1.72 \%$ which is equal to $2: 08 \%$ in the surfacing department.

\section{Procurement}

Manufacturing selecting suppliers with optical lens best brand in the world of optical lens company coming from Germany. The supplier is the leading lens manufacturer in the world that has stood since 1846 . The quality of the optical clarity of the lenses in the world no doubt, even not just make lenses for eyeglasses only, but for telescopes, microscopes, and medical devices are extremely exacting in its use.

\section{KPI Monitoring Data}

The progress of the continuous improvement is monitored by using the following KPIs described in Table 3. From the table are rejected KPI rate reduction rate is $0.46 \%$. Namely, in the year 2018 . by an average of $5.40 \%$ and by 2020 become $4.94 \%$. Then in IBC on time delivery increased by $2.22 \%$. Namely in 2018 on average by $93.06 \%$ and by 2020 became $95.28 \%$. From the results of the above development has yet to reach the target KPI that is made of $3.5 \%$ to Rejected Rate and 4 days for On-Time Delivery on all orders lens. For it was still a necessary step of sustainable development so that all KPI can be achieved and have a competitive advantage in the optical lens manufacturing industry.

Based on these results promising manufacturing successful order completion process for the optical counterparts 2 days faster than before. Such data can be seen in the Table 4. The table shows the manufacturing managed to increase competitiveness in the competition by cutting the lens order execution process time compared to 2018 (before the development) and by 2020 faster than 2 days. While the average manufacturing optical lenses, others are still 5 working days.

The results of continuous development in Rejected Rate and OTD are used as survey materials to 100 Store Managers and Optical Store Customers to find out the level of satisfaction felt to these results (Table 5 and Table 6).

The conclusion of the survey results is from the Store Managers side of the optical partner who is in charge and the head of the optical store that is often directly related to the lab and also customers. As people who understand very well about the process of making optical lenses in the lab., the store managers are mostly satisfied about the achievement of Rejected Rate which is down, although the 
decrease is less significant. They understand the obstacles faced by the lab. especially on weekends, where sales are quite high, as a result there is often an overcapacity of production resulting in frequent failures. For OTD increase, Store Managers is very satisfied about the acceleration of 2 days process in optical lens manufacturing production service so that it can be used as a selling point for customers when offering lenses, because the average process of appointment time completed in competitors is still 7 days.
In terms of customers the result of rejected rate decrease was responded with great dissatisfaction. This is because customers do not want to know about the obstacles faced by the factory, and for them glasses are a much needed thing so they do not want any process to fail. As for the increase in OTD responded with satisfaction, but the average customer has the hope that the process can be faster than the process time.

Table 1. The Time Limit of Lens Production Process

\begin{tabular}{llr}
\hline \multicolumn{1}{c}{ Step } & \multicolumn{1}{c}{ Process } & Time Limit \\
\hline Surfacing & Calculating, Blocking, Tapping Generating, Engraving, Polish, Deblocking & 60 Minutes \\
Tinting & Tinting & 60 minutes \\
Coating & Precleaning, Hardcoat, Multicoat & 300 Minutes \\
Edging & Edging & 12 Minutes \\
\hline \multicolumn{2}{c}{ Total Process } & 432 Minutes \\
\hline
\end{tabular}

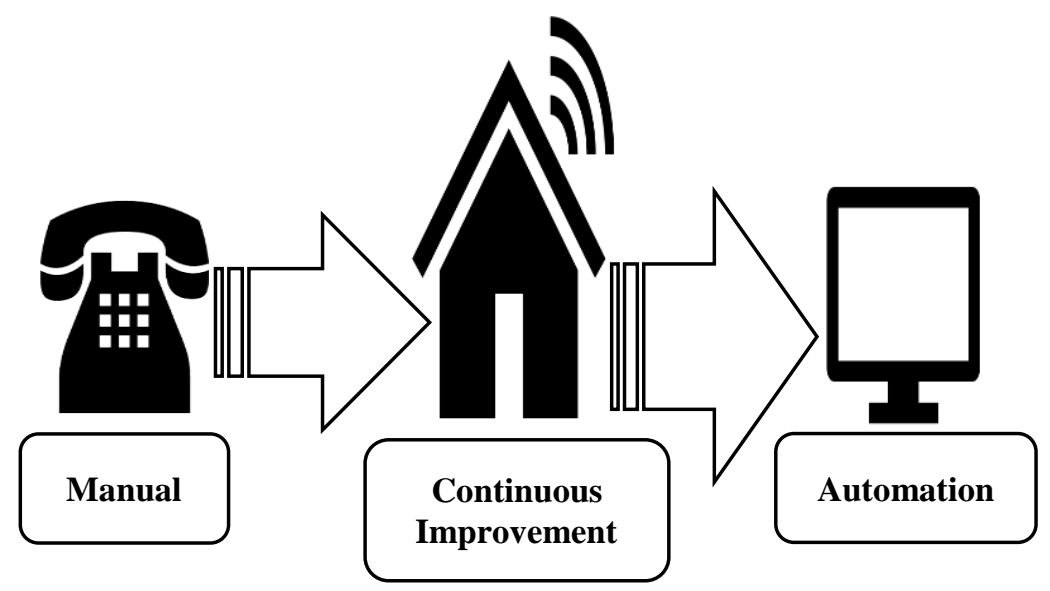

Figure3. Continuous Improvement Process

Table 2. The Data of Rejected Rate at the Surfacing Department

\begin{tabular}{ccccccc}
\hline \multicolumn{7}{c}{ Rejected Rate on Surfacing as Result of Automation } \\
\hline Year & Jan & Feb & Mar & Apr & May & Avg \\
\hline 2018 & $3.79 \%$ & $3.05 \%$ & $3.58 \%$ & $3.36 \%$ & $5.19 \%$ & $3.80 \%$ \\
2019 & $1.79 \%$ & $2.13 \%$ & $2.08 \%$ & $1.34 \%$ & $1.23 \%$ & $1.72 \%$ \\
\hline
\end{tabular}

Table 3. KPIs Monitoring Data of Rejected Rate \& On Time Delivery

\begin{tabular}{|c|c|c|c|c|c|c|c|}
\hline \multicolumn{2}{|c|}{2018} & Jan & Feb & Mar & Apr & May & Avg \\
\hline \multicolumn{2}{|c|}{ Rejected Rate } & $5.52 \%$ & $5.10 \%$ & $4.53 \%$ & $5.53 \%$ & $6.51 \%$ & $5.40 \%$ \\
\hline OTD & 0 to 4 days & $94.15 \%$ & $95.61 \%$ & $94.31 \%$ & $91.23 \%$ & $89.99 \%$ & $93.06 \%$ \\
\hline OFTD & $>=4$ days & $5.85 \%$ & $4.39 \%$ & $5.69 \%$ & $8.77 \%$ & $10.01 \%$ & $6.94 \%$ \\
\hline \multicolumn{2}{|c|}{2020} & Jan & Feb & Mar & Apr & May & Avg \\
\hline \multicolumn{2}{|c|}{ Rejected Rate } & $5.06 \%$ & $4.99 \%$ & $5.80 \%$ & $4.94 \%$ & $3.91 \%$ & $4.94 \%$ \\
\hline OTD & 0 to 4 days & $94.40 \%$ & $97.55 \%$ & $98.14 \%$ & $94.14 \%$ & $92.18 \%$ & $95.28 \%$ \\
\hline OFTD & $>=4$ days & $5.60 \%$ & $2.45 \%$ & $1.86 \%$ & $5.86 \%$ & $7.82 \%$ & $4.72 \%$ \\
\hline
\end{tabular}


Table 4. Customers Time Appointment of Completed Orders

\begin{tabular}{cccccc}
\hline Optical & $\begin{array}{c}\text { Time to } \\
\text { Send Data } \\
\text { Orders to } \\
\text { the Lab. } \\
\text { Server }\end{array}$ & $\begin{array}{c}\text { All Optical } \\
\text { Stores } \\
\text { Jadetabek }\end{array}$ & $\begin{array}{c}\text { Jogja, Bandung, } \\
\text { Semarang, Cikarang, } \\
\text { Bogor, Medan, Pekanbaru, } \\
\text { Makasar, Manado, Bali, } \\
\text { Lombok, Pontianak, } \\
\text { Banjarmasin }\end{array}$ & $\begin{array}{c}\text { Cirebon, Kediri, } \\
\text { Kudus, Sidoarjo, } \\
\text { Solo, Madura, } \\
\text { Magelang, Jambi, } \\
\text { Batam, Palembang, } \\
\text { Samarinda, Malang }\end{array}$ & $\begin{array}{c}\text { Palu, } \\
\text { Gorontalo, } \\
\text { Madiun }\end{array}$ \\
\hline Orders & $<3 \mathrm{pm}$ & $\begin{array}{c}\mathrm{D}+3 \\
\mathrm{D}+4\end{array}$ & $\mathrm{D}+5$ & $\mathrm{D}+7$ & $\mathrm{D}+8$ \\
\hline \multirow{3}{*}{ Orders } & $<3 \mathrm{pm}$ & & Before Doing The Improvement & & \\
\hline
\end{tabular}

Table 5. Store Managers Satisfaction Survey Data

\begin{tabular}{cccc}
\hline KPI & Unsatisfied & Satisfied & Very Satisfied \\
\hline Rejected Rate & 20 & 59 & 21 \\
On Time Delivery & 7 & 39 & 54 \\
\hline
\end{tabular}

Table 6. Customers Satisfaction Survey Data

\begin{tabular}{cccc}
\hline KPI & Unsatisfied & Satisfied & Very Satisfied \\
\hline Rejected Rate & 60 & 29 & 11 \\
On Time Delivery & 15 & 51 & 34 \\
\hline
\end{tabular}

\section{CONCLUSION}

Based on these results it can be concluded several things as follows: that the Kaizen work culture that focuses on sustainable development is very effectively to improve the quality of products and services for the production and manufacture of optical lenses. Determination is also very good KPI to measure the development of the Performance and create a goal that will be addressed by the company. Value Chain Analysis from Porter is well used for overall sustainable development, so that all departments in organisation are involved. Continuous improvement is very effective to increase competitive advantage. Continuous improvement should also pay attention to the level of final customer satisfaction. Customers are involved in the continuous development process in order to be in accordance with customer expectations. From the survey results of customer satisfaction level, continuous improvement must still be carried out to full fill the wishes and satisfaction of customers.

\section{REFERENCES}

Abdulmouti, H. (2018). Benefits of Kaizen to Business Excellence: Evidence from a Case Study. Industrial Engineering \& Management, 7(2), 2169-0316. doi:10.4172/21690316.1000251.

Cegliński, P. (2016). The concept of competitive advantages. logic, sources, and durability. Journal of Positif Management, 7(3), 57-70. doi: 10.12775/JPM.2016.016.

Ehsani, Z., \& Ehsani, M. H. (2015). Effect of quality and price on customer satisfaction and commitment in Iran auto industry. International Journal of Service Sciences, Management and Engineering, 5(1), 52-56. Retrieved from http://www. openscienceonline.com/journal/ssme.

Herdiansyah, H. (2010). Metode penelitian kualitatif untuk ilmuilmu sosial. Jakarta: Salemba Humanika. 
Hoe, L. C., \& Mansori, S. (2018). The effects of product quality on customer satisfaction and loyalty: evidence from Malaysian engineering industri. International Journal of Industrial Marketing, 3(1), 20-35. doi:10.5296/ijim.v3i1. 13959.

Huff, A. S., Floyd, S. W., Sherman, H. D., \& Terjesen, S. (2009). Strategic management. logic and action. New York: John Wiley \& Sons.

Imai, M. (2008). The Kaizen power. Alih Bahasa: Sigit Pranowo, Yogyakarta.

Izogo, E. E., \& Ogba, I. E. (2015). Ogba service quality, customer satisfaction and loyalty in automobile repair services sector. International Journal of Quality \& Reliability Management, 32(3), 250-269. doi. 10.1108/IJQRM-05-20130075.

ISO 22400 (2014). Automation systems and integration - key performance indicators (KPIs) for manufacturing operations management.

Joergensen, F., Boer, H., \& Laugen, B.T. (2006). CI implementation: an empirical test of the CI maturity model. Creativity and Innovation Management, 15(4), 328-337. doi: 10.1111/j.1467-8691.2006.00404.

Khan, H. U. Ali, S., \& Hongqi, L. (2018). Impact of continous improvement on organization performance insight from Pakistan : an empirical study. International Journal of Innovation, Management and Technology, 9(1), 7-14.

Kotler, P., \& Amstrong, G. 2012. Principle of marketing.14th edition. New Jersey, Published by Prentice Hall.

Kumar, R. (2019). Kaizen a tool for continuous quality improvement in Indian manufacturing Organization. International Journal of Mathematical, Engineering and Management Sciences 4(2), 452-459. doi:10.33889/IJMEMS.2019.4.2-037
Li Zhu, C., Johnsson, J., Mejvik, M., Varisco, \& Schiraldi, M. (2017). Key performance indicators for manufacturing operations manage-ment in the process industry, 2017 IEEE International Conference on Industrial Engineering and Engineering Management (IEEM), 969-973. doi: 10.1109/IEEM.2017. 8290036.

Nawawi, H. (2003). Kepemimpinan Mengefektifkan Organisasi. Yogyakarta: Gajah Mada University Press.

Pearce, J. A., \& Robinson, R. B. (2013). Manajemen strategis: formulasi, implementasi, dan pengendalian. Jakarta: Salemba Empat.

Porter, E. M. (1985). Competitive advantage-creating and sustaining superior performance. New York: Free Press.

Robbin P. S. (2002), Organizational behavior principles (Fifth edition). Jakarta: the publisher.

Santoso, S., \& Mayrifka, D. (2019). Analysis problem and improvement of appearance aesthetics product model HC C5 / XT with method of Plan-Do-Check-Action (PDCA) in PT. XXXX. International Journal of Innovative Science and Research Technology, 4(11), 2456-2165.

Sugiyono, S. (2010). Research method quantitative and qualitative $R \& D$. Bandung: Alfabeta.

Tjiptono, F. (2008). Strategi pemasaran (Edisi Kedua). Yogyakarta: Andi Offset.

Velimirović, D., Velimirović, M. \& Stanković, R. (2011). Role and importance of key performance indicators measurement. Serbian Journal of Management, 6(1), 63 72.

Wang, H. L. (2014). Theories for competitive advantage, in: Hasan, $\mathrm{H}$. (Ed.), Being Practical with Theory: A Window into Business Research, Wollongong, Australia: Theory, Australia, 33-43. 
Warren, J. (2011). Key performance indicators (KPI) - definition and action: integrating KPIs into your company's strategy. London: ATI. 